\title{
VARIATION OF FOOD ITEMS IN THE STOMACH CONTENTS OF TWO MULLETS, CHELON SUBVIRIDIS AND VALAMUGIL BUCHANANI, FROM MERBOK ESTUARY, KEDAH, MALAYSIA
}

\author{
Kaniz Fatema*, Wan Maznah Wan Omar ${ }^{1}$ and Mansor Mat Isa ${ }^{1}$ \\ Department of Fisheries, University of Dhaka, Dhaka1000, Bangladesh
}

\begin{abstract}
This study was conducted in Merbok estuary, Kedah, Malaysia during January to December 2011 to assess monthly and seasonal variation in food items in the stomach of Chelon subviridis and Valamugil buchanani. A total of 341 fish samples (225 for Chelon subviridis and 116 for Valamugil buchanani) were collected from upper zone (Lalang and Sameling Rivers) of Merbok estuary. Among the stomach contents plant materials, diatom, cyanobacteria and detritus were the main food items in both fish species. In both fishes the highest numbers of food items were found in the month of November. Chelon subviridis consumed plant materials $65.84 \%$ by number and $8.55 \%$ by frequency of occurrence in the dry season whereas $66.25 \%$ by number and $9.73 \%$ by frequency of occurrence in the wet season. On the other hand, Valamugil buchanani consumed plant materials $59.54 \%$ by number and $12.28 \%$ by frequency of occurrence in the dry season whereas $72.89 \%$ by number and $11.96 \%$ by frequency of occurrence in the wet season respectively. Monthly variations of diatom as food item between $C$. subviridis and $V$. buchanani were found to be statistically significant $(\mathrm{p}<0.05)$. Both of the fish species consumed more food (by numerical method) in wet season than dry season.
\end{abstract}

Key words: Variation of food items, Chelon subviridis and Valamugil buchanani

\section{INTRODUCTION}

Fishes are highly responsive to seasonal changes in food availability. Changes from one trophic level to another are also known to occur. Fish may switch from a diet of invertebrates to a diet of algae as invertebrate numbers decline toward the end of summer (Kitchell and Windell 1970). Thus, to adequately describe the trophic resources utilization by a fish population, it is often necessary to sample at frequent intervals throughout the year. Analysis of gut content is widely used to ascertain the food and feeding habit of a fish species. Accurate description of diets and feeding habits provides the basis for understanding the trophic interactions in aquatic food webs (Sivadas and Bhaskaran 2009, Kariman and Khalifa 2009). Food and feeding habits of the

* Corresponding author: f.kaniz@yahoo.com. 1School of Biological Sciences, Universiti Sains Malaysia, 11800 Penang, Malaysia. Center for Marine and Coastal Studies (CEMACS), Universiti Sains Malaysia, 11800 Penang, Malaysia

(C) 2015 Zoological Society of Bangladesh DOI: $10.3329 /$ bjz.v43i2.27393 
fish vary with time of the day, season of the year, size of the fish, environmental condition and with different food substances present in the water body (Hynes 1950). The correct picture of the food and feeding habit of a fish may not be obtained by examination of the gut contents of a few specimens at random; but an intensive study of the gut contents over the various seasons of the year can yield information of the value for fisheries development and management (Pillay 1952). Wotton (1998) mentioned that many fishes display great flexibility in their feeding ecology, for example, ontogeny and seasonal changes in diet composition.

There is less information on the feeding habit of mullet fish in Malaysia especially on Merbok River estuary (Mansor et al. 2012, Fatema et al. 2013a,b). Therefore, this study was undertaken to assess the monthly and seasonal variation of food items in the stomachs of two mullet fish species (Chelon subviridis, Valamugil buchanani) which may provide some input in relation to the habitat of these fish species.

\section{MATERIAL AND METHODS}

Fish samples were collected monthly from the upper zones of Merbok estuary i. e. upstream of Lalang and Sameling River from January to December 2011. The descriptions of the sampling sites are given elsewhere (Fatema et al. 2014). The samples were collected from artisanal fishermen who operate the barrier nets, with the dimensions of the net at $100-120 \mathrm{~m}$ long, $3-5 \mathrm{~m}$ deep, and with $2.5 \mathrm{~cm}$ mesh size and without bunt. A total of 341 fish samples $(225$ for Chelon subviridis and 116 for Valamugil buchanani) were collected for the analysis of stomach contents.

Stomach contents were analyzed by two methods, such as (i) numerical and (ii) frequency of occurrence methods Hyslop (1980).

(i) Numerical method: The number of individuals in each food category was recorded for all stomachs and the total was expressed as a proportion, usually a percentage, of the total individuals in all food categories (Ikusemiju and Olaniyan 1977). The mean number of individuals per stomach in each food category was calculated.

(ii) Frequency of occurrence method: This method is a way of recording data gleaned from stomach contents for calculating the number of stomachs containing one or more individuals of each food category. This number was then expressed as a percentage of all stomachs.

Frequency of occurrence was calculated according to the formula by Hyslop (1980) and Bowen (1983):

$F i=(n i / n)^{*} 100$

Where, Fi: frequency of occurrence of the $i$ food item in the sample

$n i$ : number of stomachs in which the $i$ item is found 
$n$ : total number of stomachs with food in the sample

'Kruskal Wallis H test' was used to show any significance differences of food items among studied fishes based on numerical and frequency of occurrence method.

\section{RESULTS AND DISCUSSION}

Tables 1 and 2 show the monthly changes of food items based on numerical method in the stomachs of $C$. subviridis and $V$. buchanani. In both fish species the major monthly components of the diet were plant materials, diatom, cyanobacteria and detritus. Zooplanktons were found in every month except January in the stomach of both fish species. Desmids and pisces were the least observed item in the stomachs of both fishes. No detritus were found in both the fish species. The highest numbers of food items were found in the month of November in both fishes. The lowest was in January in C. subviridis and September in $V$. buchanani. Figures 1 and 2 show the monthly changes of food items based on frequency of occurrence method in the stomachs of $C$. subviridis and $V$. buchanani. In case of $C$. subviridis the peak zooplankton was observed in July whereas the second highest food item, diatom was found in October. On the other hand, the highest diatom was found in February in case of $V$. buchanani while the second highest observed food item was zooplankton in the month of February.

Table 1. Monthly variations of food items based on numerical method in the stomach of $C$. subviridis $(n=225)$ during 2011

\begin{tabular}{|c|c|c|c|c|c|c|c|c|c|c|c|c|}
\hline Food Items & Jan & Feb & Mar & Apr & May & Jun & Jul & Aug & Sep & Oct & Nov & Dec \\
\hline Diatoms & 20 & 150 & 122 & 593 & 203 & 128 & 328 & 417 & 68 & 342 & 309 & 144 \\
\hline Cyanobacteria & 3 & 29 & 21 & 191 & 65 & 18 & 49 & 188 & 26 & 272 & 15 & 38 \\
\hline Desmids & 0 & 13 & 0 & 1 & 0 & 0 & 2 & 7 & 0 & 11 & 0 & 1 \\
\hline $\begin{array}{l}\text { Plant } \\
\text { materials }\end{array}$ & 18 & 1931 & 731 & 888 & 459 & 391 & 979 & 271 & 167 & 286 & 2363 & 96 \\
\hline Zooplankton & 0 & 42 & 34 & 60 & 31 & 55 & 207 & 20 & 46 & 63 & 57 & 33 \\
\hline Detritus & - & - & - & - & - & - & - & - & - & - & - & - \\
\hline Sand grains & - & - & - & - & - & - & - & - & - & - & - & - \\
\hline $\begin{array}{l}\text { Pisces (bones, } \\
\text { scales) }\end{array}$ & 0 & 0 & 2 & 2 & 0 & 0 & 0 & 0 & 7 & 1 & 1 & 0 \\
\hline Total & 41 & 2165 & 910 & 1735 & 758 & 592 & 1565 & 903 & 314 & 975 & 2745 & 312 \\
\hline
\end{tabular}




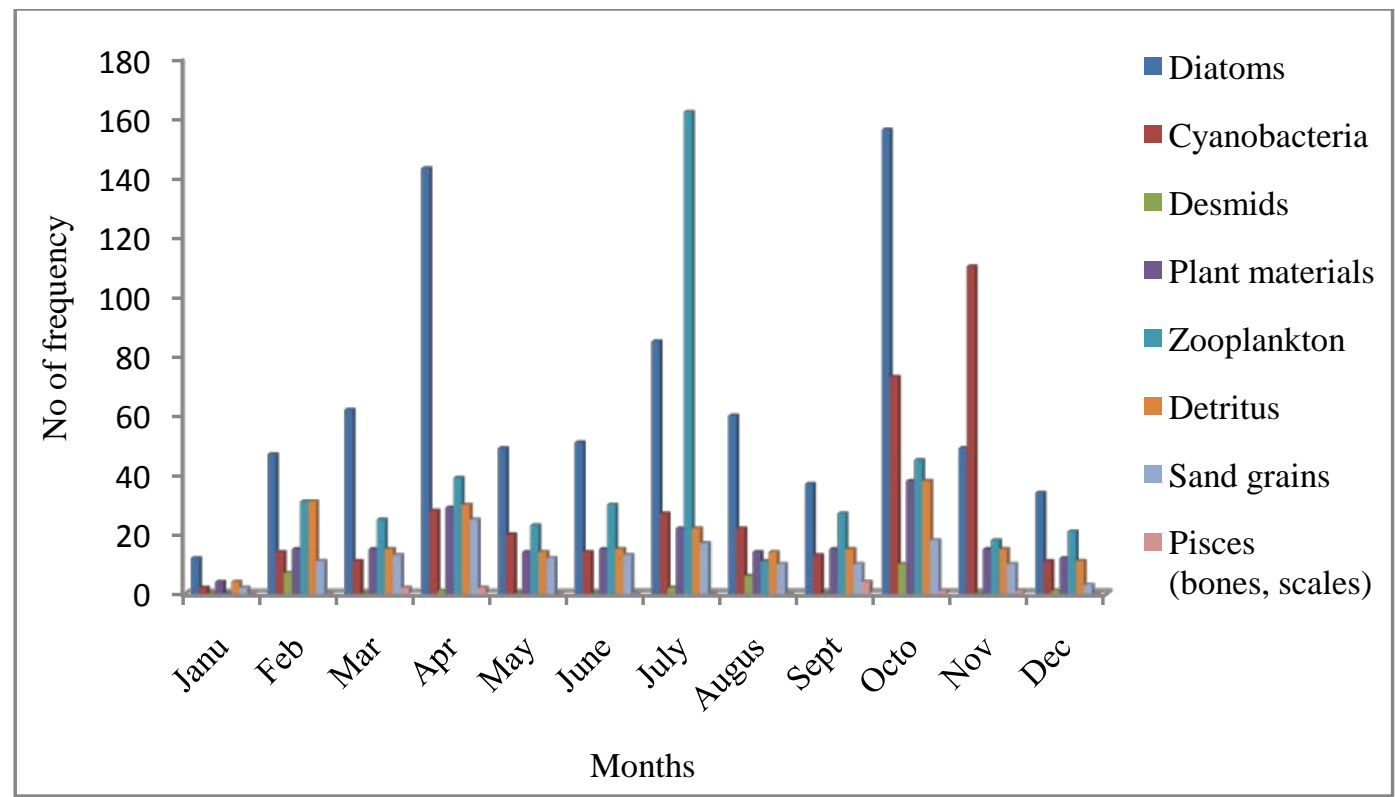

Fig. 1. Monthly variation of food items based on frequency of occurrence method in the stomachs of $C$. subviridis.

Table 2. Monthly variations of food items based on numerical method in the stomach of $V$. buchanani $(n=116)$ during 2011

\begin{tabular}{lcccccccccccc}
\hline \multicolumn{1}{c}{ Food items } & Jan & Feb & Mar & April May & Jun & July & August Sept & Octo & Nov. & De \\
\hline Diatoms & 102 & 473 & 35 & 38 & 168 & - & 23 & 63 & 4 & 56 & 291 & 32 \\
Cyanobacteria & 17 & 27 & 6 & 2 & 36 & - & 3 & 60 & 2 & 6 & 69 & 18 \\
Desmids & 1 & 5 & 0 & 0 & 2 & - & 1 & 1 & 0 & 1 & 3 & 0 \\
Plant materials & 70 & 1115 & 241 & 441 & 416 & - & 118 & 216 & 7 & 54 & 1336 & 69 \\
Zooplankton & 24 & 124 & 24 & 46 & 33 & - & 12 & 11 & 6 & 27 & 80 & 8 \\
Detritus & - & - & - & - & - & - & - & - & - & - & - & - \\
Sand grains & - & - & - & - & - & - & - & - & - & - & - & - \\
Pisces & & & & & & & & & & & & \\
(bones, scales) & 0 & 6 & 1 & 0 & 1 & - & 0 & 0 & 1 & 0 & 5 & 3 \\
\hline Total & 214 & 1750 & 307 & 527 & 656 & - & 157 & 351 & 20 & 144 & 1784 & 130 \\
\hline
\end{tabular}

*No samples were found in the month of June

Kruskal- Wallis H-test showed that monthly variations of food items between C. subviridis and $V$. buchanani were not statistically significant ( $>0.05)$ except diatom $(\mathrm{p}<0.05)$ based on numerical method. This test also showed that monthly 
variations of food items between $C$. subviridis and $V$. buchanani were statistically significant $(p<0.05)$ except desmid and pisces $(p>0.05)$ based on frequency of occurrence method. Therefore, in both methods diatom showed its variation between $C$. subviridis and $V$. buchanani.

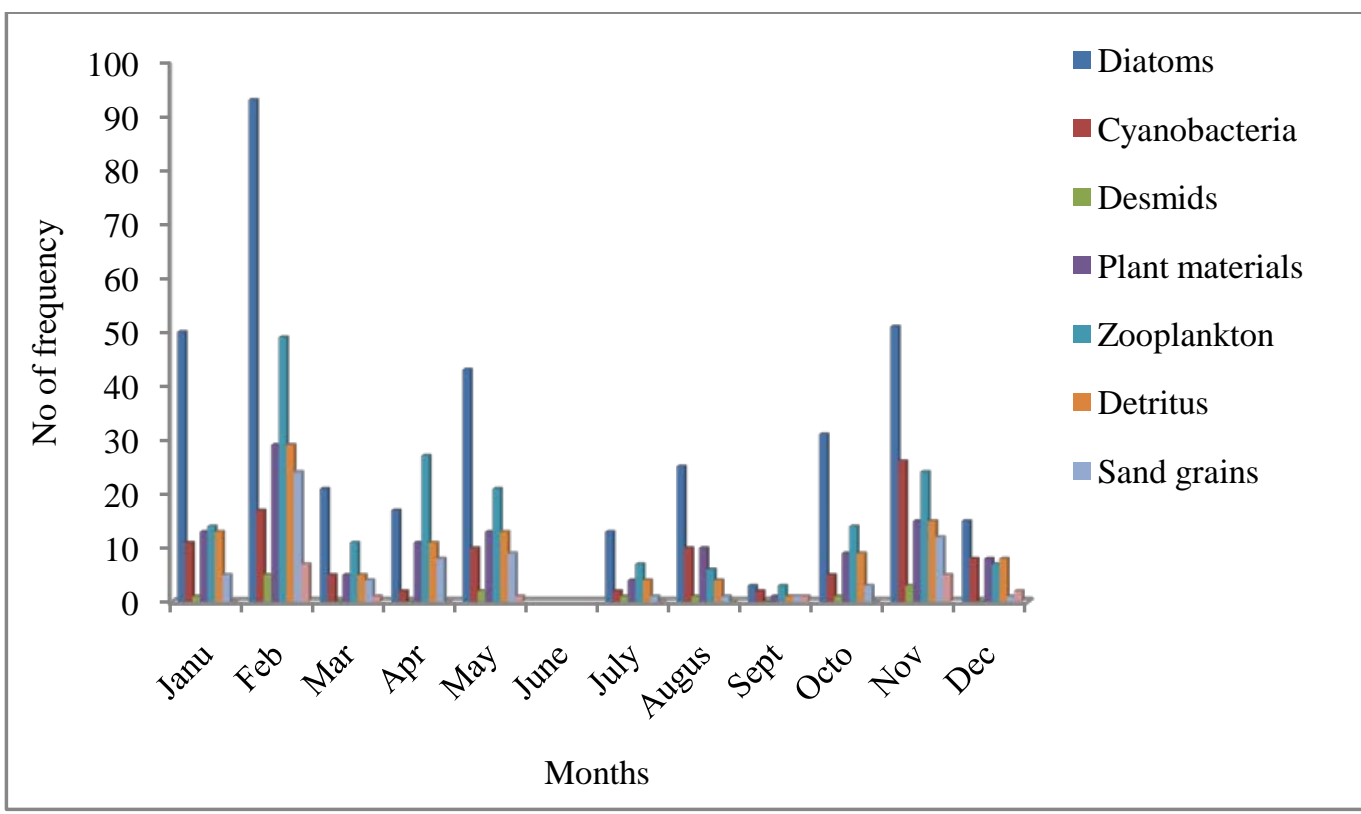

Fig. 2. Monthly variations of food items based on frequency of occurrence method in the stomachs of $V$. buchanani.

The seasonal variation of the stomach contents of $C$. subviridis and $V$. buchanani examined for Merbok estuary is presented in Tables 3 and 4. Both $C$. subviridis and $V$. buchanani consumed mainly of plant materials in the dry and rainy season respectively. In both fish species plant materials consumed were 65.84 and $59.54 \%$ by number and 8.55 and $12.28 \%$ by frequency of occurrence in the dry season and 66.25 and $72.89 \%$ by number and 9.73 and $11.96 \%$ by frequency of occurrence in the wet season respectively (Table 3 and 4) .The diatoms were next in abundance with 19.78 and $28.64 \%$ by number in the dry season and 23.25 and $16.43 \%$ by number in the rainy season. In both fish species, diatoms were the most consumed item with 35.03 and $39.38 \%$ by frequency method in the dry season and 38.17 and $34.78 \%$ in the wet season respectively. Zooplanktons were next in abundance after diatom with 26.30 and $17.74 \%$ by frequency of occurrence in the dry season; 13.65 and $20 \%$ in the wet season. In both seasons desmids and pisces were the least consumed food items in the stomach of both fish species. 
Table 3. Summary of the seasonal variation in the stomach contents of $C$. subviridis from Merbok estuary (January to December, 2011) $(\mathrm{n}=225)$

\begin{tabular}{|c|c|c|c|c|c|c|c|c|}
\hline \multicolumn{5}{|c|}{ Dry season } & \multicolumn{4}{|c|}{ Wet season } \\
\hline \multirow[t]{2}{*}{ Food Items } & \multicolumn{2}{|c|}{$\begin{array}{c}\text { Numerical } \\
\text { method }\end{array}$} & \multicolumn{2}{|c|}{$\begin{array}{c}\text { Frequency of } \\
\text { Occurrence method }\end{array}$} & \multicolumn{2}{|c|}{$\begin{array}{l}\text { Numerical } \\
\text { method }\end{array}$} & \multicolumn{2}{|c|}{$\begin{array}{c}\text { Frequency of } \\
\text { Occurrence method }\end{array}$} \\
\hline & No & $\%$ & No & $\%$ & No & $\%$ & No & $\%$ \\
\hline Diatoms & 1112 & 19.78 & 385 & 35.03 & 1712 & 23.25 & 400 & 38.17 \\
\hline Cyanobacteria & 380 & 6.76 & 141 & 12.83 & 506 & 6.87 & 204 & 19.47 \\
\hline Desmids & 27 & 0.480 & 20 & 1.82 & 8 & 0.109 & 7 & 0.668 \\
\hline Plant materials & 3701 & 65.84 & 94 & 8.55 & 4879 & 66.25 & 102 & 9.73 \\
\hline Zooplankton & 400 & 7.12 & 289 & 26.30 & 248 & 3.37 & 143 & 13.65 \\
\hline Detritus & - & - & 105 & 9.55 & - & - & 103 & 9.83 \\
\hline Sand grains & - & - & 64 & 5.82 & - & - & 80 & 7.63 \\
\hline $\begin{array}{l}\text { Pisces (bones, } \\
\text { scales) }\end{array}$ & 1 & 0.018 & 1 & 0.091 & 12 & 0.163 & 9 & 0.859 \\
\hline Total & 5621 & & 1099 & & 7365 & & 1048 & \\
\hline
\end{tabular}

Table 4. Summary of the seasonal variation in the stomach contents of $V$. buchanani from Merbok estuary (January to December, 2011) (n = 116)

\begin{tabular}{|c|c|c|c|c|c|c|c|c|}
\hline \multicolumn{5}{|c|}{ Dry season } & \multicolumn{4}{|c|}{ Wet season } \\
\hline \multirow[t]{2}{*}{ Food Items } & \multicolumn{2}{|c|}{$\begin{array}{c}\text { Numerical } \\
\text { method }\end{array}$} & \multicolumn{2}{|c|}{$\begin{array}{c}\text { Frequency of } \\
\text { Occurrence method }\end{array}$} & \multicolumn{2}{|c|}{$\begin{array}{c}\text { Numerical } \\
\text { method }\end{array}$} & \multicolumn{2}{|c|}{$\begin{array}{c}\text { Frequency of } \\
\text { Occurrence method }\end{array}$} \\
\hline & No & $\%$ & No & $\%$ & No & $\%$ & No & $\%$ \\
\hline Diatoms & 686 & 28.64 & 202 & 39.38 & 599 & 16.43 & 160 & 34.78 \\
\hline Cyanobacteria & 71 & 2.96 & 43 & 8.38 & 175 & 4.80 & 55 & 11.96 \\
\hline Desmids & 8 & 0.334 & 8 & 1.56 & 6 & 0.165 & 6 & 1.30 \\
\hline Plant materials & 1426 & 59.54 & 63 & 12.28 & 2657 & 72.89 & 55 & 11.96 \\
\hline Zooplankton & 195 & 8.14 & 91 & 17.74 & 200 & 5.49 & 92 & 20 \\
\hline Detritus & - & - & 63 & 12.28 & - & - & 49 & 10.65 \\
\hline Sand grains & - & - & 34 & 6.63 & - & - & 35 & 7.61 \\
\hline $\begin{array}{l}\text { Pisces (bones, } \\
\text { scales) }\end{array}$ & 9 & 0.376 & 9 & 1.75 & 8 & 0.219 & 8 & 1.74 \\
\hline Total & 2395 & & 513 & & 3645 & & 460 & \\
\hline
\end{tabular}

Present study observed that both the fish species C. subviridis and $V$. buchanani fed on plant materials, diatom, zooplankton, cyanobacteria, sand grain, detritus, desmid and pisces in the dry and wet season respectively. This study also indicated that both fish species fed more food (by numerical method) in wet season as compared to dry season. Labropoulou et al. (1997) studied the ontogenic, feeding trends and seasonal changes in trophic biology of striped red 
mullet. They reported that crustaceans such as amphipods and decapods were the prominent diet of striped red mullet which varied with season. Cardona (2000) stated that seasonal changes in the food quality, dial feeding rhythm and growth rate of juvenile leaping grey mullet (Liza saliens). The author also reported that there was a relationship between the summer season food and reduced fish growth. These research findings comply with the previous study results. The foods of four juvenile mugilid fishes such as Liza falcipinnis, $L$. dumerili, Mugil bananensis and M. curema were composed of bacteria, diatoms, blue green algae, protozoan, detritus and particulate organic matter (Blay 1995) with no remarkable seasonal changes in the diet and feeding activities (Blay1995 and Soyinka 2008).

In this study plant material, diatoms, cyanobacteria and detritus were main food items in the stomach contents of Chelon subviridis and Valamugil buchanani by both frequency of occurrence and numerical method. Fish feeding rate in both the species were found to be decreased during dry season than wet season. Monthly and seasonal variation was noticed in the consumed food items of two fish species by both the methods.

\section{LITERATURE CITED}

BLAY, J. 1995. Food and feeding habits of four species of juvenile mullet (Mugilidae) in a tidal lagoon in Ghana. J. Fish Biology, 46(1): 134-141.

BOWEN, S. H. 1983. Quantitative description of the diet. In : Nilesen, L,A.; Johnson, D.L. (ed.) Fisheries techniques. Maryland: American Fisheries Society: 325-336.

CARDONA, L. 2000. Effects of salinity on the habitat selection and growth performance of Mediterranean flathead grey mullet, Mugil cephalus (Osteichthyes, Mugilidae). Estuarine Coastal and Shelf Sci, 50(5): 727-737.

FATEMA, K., WAN MAZNAH, W.O. and MANSOR, M.I. 2014. Spatial and temporal variation of physico-chemical parameters in Merbok estuary, Kedah, Malaysia. Tropical Life Science Research 25(2):1-19.

FATEMA, K., WAN MAZNAH, W. O. and MANSOR, M. I. 2013a. Identification of food and feeding habits of Mullet fish, Liza subviridis (Valenciennes, 1836) and Valamugil buchanani (Bleeker, 1853) from Merbok estuary, Kedah, Malaysia. J. Life Sciences and Technologies $\mathbf{V}(1)$ : 47-50.

FATEMA, K., WAN MAZNAH, W. O. and MANSOR, M. I. 2013b. Factors influencing zooplankton feeding of blue tail mullet and green back mullet fish species in a tropical estuary. Proceedings of the $2^{\text {nd }}$ International Conference on Agriculture, Environment and Humanities Engineering (ICAEHE' 2013). 25 th-26th August 2013, Grand Seasons Hotel, Kuala Lumpur, Malaysia, 108-110 pp.

HYNES, H.B.N. 1950. The food of fresh-water sticklebacks (Gasterosteus aculeatus and Pygosteus pungitius), with a review of methods used in studies of the food of fishes. J. Animal Ecology, 19(1): 36-58.

HYSLOP, E.J. 1980. Stomach contents analysis-a review of methods and their application. J. Fish Biology, 17(4): 411-429. 
IKUSEMIJU, K. and OLANIYAN, C. 1977. The food and feeding habits of the catfishes, Chrysichthys walkeri (Gunther), Chrysichthys filamentosus (Boulenger) and Chrysichthys nigrodigitatus (Lacépède) in the Lekki Lagoon, Nigeria. J. Fish Biology, 10(2): 105-112.

KARIMAN, A. S. and KHALIFA, N. 2009.Stomach contents and feeding habits of Oreochromis niloticus (L.) from Abu-Zabal Lakes, Egypt; World Applied Sciences Journal 6(1), 01-05.

KITCHELLl, J. F.and WINDELL1, J. T. 1970. Nutritional value of algae to bluegill sunfish, Lepomis macrochirus. Copeia, 1: 18-190.

LABROPOULOU, M., MACHIAS, A., TSIMENIDES, N. and ELEFTHERIOU, A. 1997. Feeding habits and ontogenetic diet shift of the striped red mullet, Mullus surmuletus Linnaeus, 1758. Fisheries Research, 31(3): 257-267.

MANSOR, M. I., MOHAMMAD ZAFRIZAL, M., NUR-FADHILAH, M., KHAIRUN, Y. and WAN MAZNAH, W. O. 2012 a. Temporal and spatial variations in fish assemblage structures in relation to the physicochemical parameters of the Merbok River estuary, Kedah. J. Natural Sciences Research, 2(7): 110-127.

PILLAY, T. V. R. 1952. A critique of the methods of study of food of fishes. J. Zool. Society India, 4 (2): 185-200.

SIVADAS, M. and BHASKARAN, M. 2009. Stomach content analysis of the Indian mackerel, Rastrelliger kanagurta (Cuvier) from Calicut, Kerala. Indian J. Fisheries, 56(2): 143-146.

SOYINKA, O. O. 2008. The feeding ecology of Mugil cephalus (Linnaeus) from a high brackish tropical lagoon in South-west, Nigeria. African J. Biotechnology, $\mathbf{7}(22)$ : 4192-4198.

WOOTTON, R. J. 1998. Ecology of Teleost Fishes. London: Kluwer Academic Publications. 